\title{
Stress-related gene transcription in fish exposed to parasitic larvae of two freshwater mussels with divergent infection strategies
}

\author{
Andrée D. Gendron ${ }^{1, *}$, David Sanchez ${ }^{1,3}$, Mélanie Douville ${ }^{2}$, Magali Houde ${ }^{1}$ \\ ${ }^{1}$ Aquatic Contaminants Research Division, Water Science and Technology Directorate, \\ Environment and Climate Change Canada, 105 McGill, Montreal, Quebec H2Y 2E7, Canada \\ ${ }^{2}$ Environmental Emergencies Division, Environmental Protection Operations Directorate, \\ Environment and Climate Change Canada, 105 McGill, Montreal, Quebec H2Y 2E7, Canada \\ ${ }^{3}$ Present address: Inocucor, 7720 Frederic Banting, Suite 100, Montreal, Quebec H4S 2A1 Canada
}

\begin{abstract}
Freshwater unionoid mussels have a unique life cycle involving a temporary parasitic phase. Their larvae (glochidia) attach to the gills or fins of fish hosts where they remain encysted until metamorphosis into free-living juveniles. The physiological response of fish during the critical period of glochidial attachment is not well understood, but recent work suggests that glochidia retention and survival is enhanced in stressed and cortisol-injected hosts. In this study, the early changes induced by glochidiosis were investigated for the first time at the transcriptional level. In 2 separate experiments, juvenile yellow perch Perca flavescens were inoculated with glochidia of Elliptio complanata (a host generalist) and Lampsilis radiata (a host specialist) following a standardized procedure. The transcriptional levels of 5 genes involved in the fish response to stress were assessed in the host liver and gills $24 \mathrm{~h}$ post-infection using quantitative real-time PCR. The number of encysted glochidia did not significantly differ between fish inoculated with E. complanata and L. radiata. Both species induced a 3-fold increase of $70 \mathrm{kDa}$ heat-shock protein gene (hsp 70) transcription in host liver. However, only E. complanata influenced the transcription of cortisol-regulated genes, notably glucocorticoid receptor DNA-binding factor 1 (grlf1). This gene, known to modulate tissue responsiveness to cortisol, was downregulated in infected fish compared to controls. Our findings suggest that different glochidia species interact with their fish host in distinct ways. Additional studies are required to address this hypothesis and further investigate the significance of the observed host transcriptional responses.
\end{abstract}

KEY WORDS: Host response - Gene transcription - Glucocorticoid - Heat-shock proteins · Glochidia $\cdot$ Elliptio $\cdot$ Lampsilis $\cdot$ Perca flavescens

\section{INTRODUCTION}

Freshwater mussels belonging to the order Unionoida depend on aquatic vertebrates, mainly fish, for their reproduction and dispersal (Haag 2012). Their larvae, called glochidia, are microscopic bivalves that attach to the gills, fins or external structures of their hosts where they become encapsulated. After a lapse of time varying from days to months (Watters \&

\footnotetext{
*Corresponding author: andree.gendron@canada.ca
}

O'Dee 1999, Reis et al. 2014), these parasitic larvae metamorphose into juvenile mussels which then leave their host and settle in the sediment where they assume a free-living existence (Watters \& O'Dee 1998, Fisher \& Dimock 2002).

Although some unionoids develop successfully on a large array of fish species (Van Snik Gray et al. 2002, Lellis et al. 2013), others have a narrow host specificity (Barnhart et al. 1998) and have evolved

() The authors 2019. Open Access under Creative Commons by Attribution Licence. Use, distribution and reproduction are unrestricted. Authors and original publication must be credited. 
strategies to selectively attract hosts which are most likely to ensure the survival and metamorphosis of their larvae (Zanatta \& Murphy 2006). For instance, in species of the tribe Lampsilini, the mantle is modified to mimic a prey item such as a fish or a macroinvertebrate (Barnhart et al. 2008). If a fish is lured and bites the mantle display, it ruptures the marsupium (i.e. a specialized mussel gill compartment containing the larvae), thereby freeing thousands of parasitic glochidia in close reach to the gills of this potential host (Haag \& Warren 1999). In other species, glochidia are embedded in a gelatinous matrix having the appearance of fish food items (Haag 2012). Depending on mussel species, these packets of glochidia, called conglutinates, are either released in the female's surroundings (Watters 1999, 2002) or remain attached through a thin filament reminiscent of a baited fishing line (Haag et al. 1995).

Negative impacts on fish health and survival from excessive numbers of glochidia have been described (Karna \& Milemann 1978, Howerth \& Keller 2006), although, under natural conditions, glochidial infections are rarely lethal. In fact, only a fraction of the parasitic larvae to which a host is exposed will successfully clamp to its tissue (Haag 2012). The attachment is followed by the formation of a cyst as the glochidium is progressively surrounded by fish epithelial cells following a process reminiscent of a wound healing reaction (Waller \& Mitchell 1989, Rogers-Lowery \& Dimock 2006). A number of the encysted larvae are prematurely rejected as a result of localized immune reactions mounted by the host (Karna \& Milemann 1978). These reactions consisting of inflammation, hyperplasia and cell infiltration are much more pronounced and pervasive in unsuitable hosts as well as in suitable hosts having previously experienced glochidial infections (Karna \& Milemann 1978, Waller \& Mitchell 1989). Several studies have indeed demonstrated the development of an acquired immune response to glochidiosis that confers immunity to the hosts (Bauer \& Vogel 1987, O'Connell \& Neves 1999, Dodd et al. 2006); this acquired immunity can allow them to resist subsequent infections by other glochidia species (Dodd et al. 2005).

The physiological changes induced in fish by glochidial infections have been investigated in a few studies (Table 1). Effects reported range from increased levels of circulating lactate and glucocorticoids (cortisol), elevated haematocrit and disturbed blood ion balance and enzymatic profiles to increased ventilation rate and reduced fish growth and condition (Kaiser 2005, Treasurer et al. 2006, Duban- sky et al. 2011, Thomas et al. 2014, Douda et al. 2017, Filipsson et al. 2017, Ooue et al. 2017). The direction and magnitude of these changes vary greatly among studies, probably as a result of the disparities in experimental settings (i.e. intensity and duration of exposure), in the timing of endpoint measurements and in species combinations (Table 1). For instance, in a study experimentally exposing bluegill sunfish Lepomis macrochirus to glochidia of Utterbackia imbecillis, the predominant physiological effect observed was the marked rise in host plasma cortisol levels at high infection intensity (Dubansky et al. 2011). Glochidia of this species were also more likely to undergo successful metamorphosis when attached to fish hosts exhibiting high circulating cortisol or to those given an intraperitoneal injection of cortisol prior to the infection experiments, than to unstressed fish (Dubansky et al. 2011). These findings likely reflect a stress-induced suppression of the host innate immune defense (Tort 2011), preventing the premature shedding of glochidia. However, when exposing the same host (L. macrochirus) to a different species of glochidia (Lampsilis siliquoidea), only slight differences in the success of metamorphosis between the high and low stress treatments were observed, and no relationship between infection intensity and glochidia survivorship was found (Douda et al. 2018). Douda et al. (2017) also failed to detect a significant cortisol response to infection when they exposed European chub Squalius cephalus to glochidia of Sinanodonta woodiana. Altogether, these findings suggest species-specific patterns of physiological response to glochidial infection, which deserve further examination.

The objectives of this research were (1) to investigate the early changes induced by glochidial infections on the transcription levels of genes playing key roles in the physiological and cellular response of fish to stress and (2) to determine if the gene transcription patterns differed when fish were exposed to glochidia of mussel species with different host specificity and infection strategies. The eastern lampmussel Lampsilis radiata and the eastern elliptio Elliptio complanata, 2 species releasing hookless glochidia which primarily encyst on gills (Haag 2012), were used in the experiments. L. radiata attracts fish using mantle lures and is generally regarded as a host specialist, whereas E. complanata releases glochidia bound in mucous strands, a non-selective fishing gear in which fish become entangled (Barnhart et al. 2008, Lellis et al. 2013). The latter species can metamorphose on a wide range of fish and is considered a host generalist (Haag 2012, Lellis et al. 2013). Juve- 


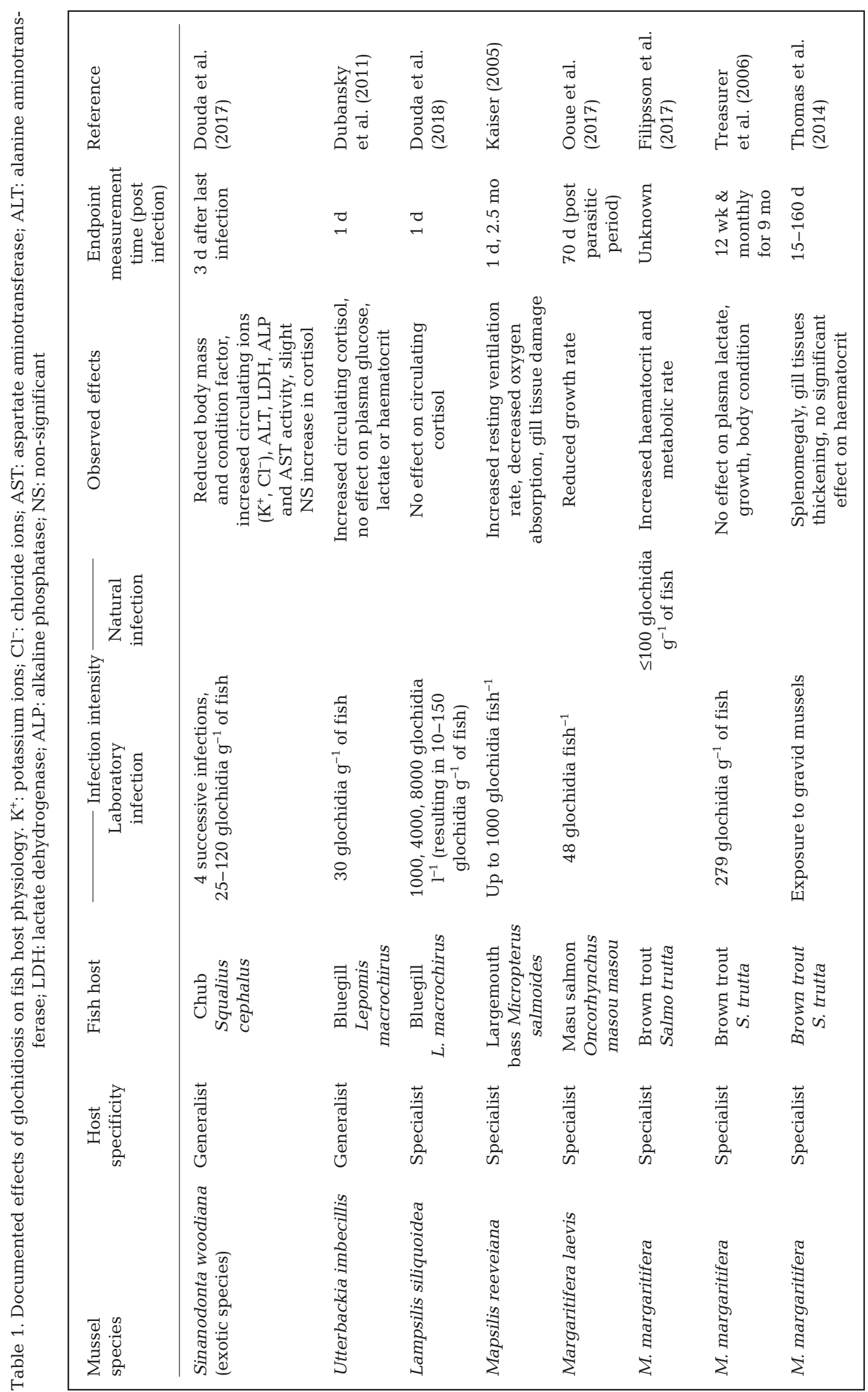


nile yellow perch Perca flavescens, an important natural host for both E. complanata and L. radiata (Tedla \& Fernando 1969, Kneeland \& Rhymer 2008, Lellis et al. 2013), were inoculated with each of these 2 glochidia species in separate experiments, and the post-infection transcription patterns were examined in the perch liver and gills for 4 genes encoding key proteins and enzymes influenced by cortisol secretion: glucose-6-phosphatase (G6P), glucose-6-phosphate dehydrogenase (G6PD), glycogen synthase (GLYC) and glucocorticoid receptor DNA binding factor (GRLF1). A glucocorticoid hormone, cortisol regulates blood glucose and the metabolism of carbohydrates, directly or indirectly affecting several enzymatic pathways (e.g. gluconeogenesis, glycogenolysis). In response to stress, cortisol is the primary hormone responsible for energy mobilization and for the maintenance and recovery of homeostasis (Mommsen et al. 1999, Polakof et al. 2012). The effect of glochidiosis on the transcription of the $70 \mathrm{kDa}$ heat-shock protein gene ( $h s p 70)$ was assessed as well. Also called molecular chaperones, HSPs ensure the proper folding and formation of proteins, and maintenance of their appropriate conformations (Roberts et al. 2010). They play a pivotal role in the cellular recovery under various stressful conditions (Padmini 2010, Roberts et al. 2010, Das et al. 2015).

\section{MATERIALS AND METHODS}

\subsection{Fish and mussel sampling and maintenance in the laboratory}

Adult Lampsilis radiata and Elliptio complanata were sampled in the St. Lawrence River, Quebec, Canada, respectively in October 2013 and July 2014 , at 2 locations: Pointe du Lac $\left(46.2784^{\circ} \mathrm{N}\right.$, $\left.72.6812^{\circ} \mathrm{W}\right)$ and Grondine $\left(46.5854^{\circ} \mathrm{N}, 72.0416^{\circ} \mathrm{W}\right)$. Gravid female L. radiata and adult-size E. complanata (this species has no sexual dimorphism) were collected by hand along the shoreline using aquascopes. Selected individuals were transported in aerated coolers filled with water from the site of capture to our facilities where they were maintained in a temperature-controlled chamber. Water in the cooler was progressively replaced with acclimated water, i.e. temperature-controlled dechlorinated water. The water treatment system used to remove residual chlorine and other waterborne contaminants/particles from municipal water combines physical filtration with activated carbon filtration and ultraviolet irradiation. Following a $24 \mathrm{~h}$ period, mussels were transferred to 381 aquaria filled with aerated acclimated water, the bottom covered with sand allowing them to bury. Specimens of L. radiata and E. Complanata were respectively maintained at 15 and $21^{\circ} \mathrm{C}$, corresponding to the water temperature in the river at the time of sampling. Both species were fed twice a week with $10 \mathrm{ml}$ of in-house cultured algae (Pseudokirchneriella subcapitata, $4 \times 10^{8}$ cells ml ${ }^{-1}$ ) and $10 \mathrm{ml}$ of a commercial suspension of concentrated aquacultured phytoplankton (Kent Marine ${ }^{\mathrm{TM}}$ ).

Yellow perch were sampled in early June 2013 and 2014 from Pointe du Lac in the St. Lawrence River $\left(46.2784^{\circ} \mathrm{N}, 72.6812^{\circ} \mathrm{W}\right)$, using a beach seine $(22.6 \mathrm{~m}$ $\times 1.15 \mathrm{~m} ; 3 \mathrm{~mm}$ mesh) pulled by hand or partially deployed from a boat. The protocol for the collection was approved by the animal care committee of Environment and Climate Change Canada according to guidelines of the Canadian Council on Animal Care (Ottawa, ON). Young-of-the-year perch $(\mathrm{n}=50)$ were transported live to the laboratory in aerated insulated containers filled with water collected at the site of capture to which sodium chloride $(\mathrm{NaCl})$ was added to minimize loss of electrolytes due to the stress of capture and confinement. Given their size and age, young-of-the-year fish were assumed to be naïve hosts, with no previous experience of glochidial infection. Fish were maintained for $24 \mathrm{~h}$ in their transportation containers, and in situ water was gradually replaced with the same conditioned water as used for mussel maintenance. Fish were thereafter transferred to two $110 \mathrm{l}$ aquaria, each provided with a recirculation and filtration unit (Aquaclear ${ }^{\circledR} 50$ filter). Water temperature was progressively raised to $21^{\circ} \mathrm{C}$, and fish were fed ad libitum with brine shrimps twice a day during the pre-experiment rearing phase (8 wk). Dissolved oxygen, ammonia, nitrite and nitrate levels were measured once a week. Water quality was maintained by renewing half of the water in the aquaria 3 times a week and by daily removal of debris sinking to the bottom.

\subsection{Glochidia collection and viability testing}

Glochidia of $L$. radiata were extracted from the marsupial gills of gravid females. Valves of the mussel were maintained open and a 26-gauge needle was inserted to slightly puncture the outer edge of the marsupial gills. Glochidia were then flushed out with dechlorinated sterile water injected with a $10 \mathrm{cc}$ syringe. Collected glochidia were allowed to sit for a few minutes in a Petri dish before being tested for viability using the sodium chloride $(\mathrm{NaCl})$ response 
test. Viable glochidia snap shut when placed in contact with a few grains of $\mathrm{NaCl}$, whereas non-viable ones remain open (Zale \& Neve 1982). Glochidia from a given female were considered usable for the experiment when $95 \%$ snapped shut in response to $\mathrm{NaCl}$ in 3 separate subsamples of 100 glochidia.

As opposed to L. radiata, females of $E$. complanata do not brood their glochidia over long periods of time (Matteson 1948, Barnhart et al. 2008, Haag 2012). In this species, gravid females release their glochidia as soon as they become mature. Released glochidia are bound in a mucoid adhesive web, sinking to the bottom and forming threads (Matteson 1948, Lellis et al. 2013). Aquaria where E. complanata were kept were inspected daily for signs of glochidial release. As soon as they were found, clusters of glochidia were collected and examined under the dissecting microscope. Glochidia were then dislodged from the mucous matrix in which they were embedded, transferred to clean dechlorinated water and tested for viability following the $\mathrm{NaCl}$ method described above.

To avoid introducing a bias due to variation in glochidial infectivity among donors (females), viable glochidia originating from 3 different female $L$. radiata were pooled prior to being used in the infection experiments. As it was impossible to trace the origin of each cluster of E. complanata, 6 were collected in 2 aquaria and pooled, to ensure at least 2 donors. Glochidia were used in infection experiments within $24 \mathrm{~h}$ of their extraction/collection.

\subsection{Glochidial infection experiments}

Because of the different timing in glochidia maturation and release between the 2 mussel species, the infection experiments were conducted separately: in August for $E$ complanata and in October for $L$. radiata. For each infection experiment, 5 fish were used as controls and 5 fish were inoculated by individual immersion in a $75 \mathrm{ml}$ plastic dish containing 15 glochidia $\mathrm{ml}^{-1}$ of water at $21^{\circ} \mathrm{C}$. A glass pipette was used to keep glochidia suspended and manually flushed towards the mouth of fish to maximize chances of glochidia being swallowed and coming into contact with the gills. Control fish were immersed in glochidia-free water and exposed to the same procedure. After 5 min of exposure, fish (control and inoculated) were removed from the dish, briefly rinsed and transferred to individual floating chambers in $110 \mathrm{l}$ aquaria for $24 \mathrm{~h}$. Chambers were partly made of nylon screening (Nytex), which allowed water re- newal but retained particles larger than $100 \mu \mathrm{m}$, including glochidia of the 2 studied species (size range measured in this study: 172-220 $\mu \mathrm{m}$ for E. complanata and 193-250 $\mu \mathrm{m}$ for L. radiata).

Twenty-four h post-inoculation, fish were euthanized (buffered tricaine methanesulfonate solution, $250 \mathrm{mg} \mathrm{l}^{-1}$ ), measured (to the nearest $0.1 \mathrm{~mm}$ ) and weighed (to the nearest $0.01 \mathrm{~g}$ ), and the number of glochidia encysted in gills, skin and fins was counted. Liver was collected and immersed in a RNA stabilization reagent (RNAlater ${ }^{\circledR}$, Thermo Fisher Scientific). Gills were cleared of encysted glochidia and preserved in the same fixative. Tissues samples were kept for $24 \mathrm{~h}$ at $4^{\circ} \mathrm{C}$, transferred to $-20^{\circ} \mathrm{C}$ for $48 \mathrm{~h}$ and stored at $-80^{\circ} \mathrm{C}$ until RNA extraction.

\subsection{Quantitative real-time PCR (qRT-PCR)}

RNA was extracted from liver and gills as previously described by Houde et al. (2014): using a sterile RNase/DNase-free pestle, 1 to $20 \mathrm{mg}$ of tissue were homogenized on ice in $50 \mu \mathrm{l}$ of buffer RLT Plus (Qiagen) followed by the addition of $550 \mu$ of buffer RLT Plus. The lysate was then centrifuged through a QIAshredder spin column (Qiagen), at $16000 \times g$ (2 min at room temperature) prior to RNA extraction using the RNeasy ${ }^{\circledR}$ plus mini kit (Qiagen). We used a microvolume spectrophotometer (NanoDropTM 1000, Thermo Fisher Scientific) to quantify RNA and assess sample purity. The $\mathrm{A}_{260} / \mathrm{A}_{280}$ ratio varied between 1.9 and 2.1 for all samples.

Reverse transcription of RNA into cDNA was achieved using the QuantiTect ${ }^{\circledR}$ Reverse transcription kit (Qiagen) following the manufacturer's instructions, with 500 ng RNA and a final reaction volume of $20 \mu \mathrm{l}$. cDNA samples were then stored at $-80^{\circ} \mathrm{C}$ until qRT-PCR analysis. Potential contamination by genomic DNA was minimized both during the RNA extraction step (gDNA eliminator columns, Qiagen RNeasy ${ }^{\circledR}$ plus mini kit) and during the reverse transcription step (gDNA wipeout buffer, Qiagen QuantiTect ${ }^{\circledR}$ Reverse transcription kit).

Target genes are listed in Table 2. They encode for enzymes/proteins whose roles are as follows: (1) G6P catalyzes the hydrolysis of glucose 6-phosphate to glucose and phosphate, the terminal steps in gluconeogenesis and glycogenolysis; (2) G6PD is responsible for the first step in the pentose phosphate pathway where glucose is converted into ribose-5phosphate; (3) GLYC combines glucose residues into a polymeric chain for storage as glycogen; (4) GRLF1 is a repressor of glucocorticoid receptor transcription; 


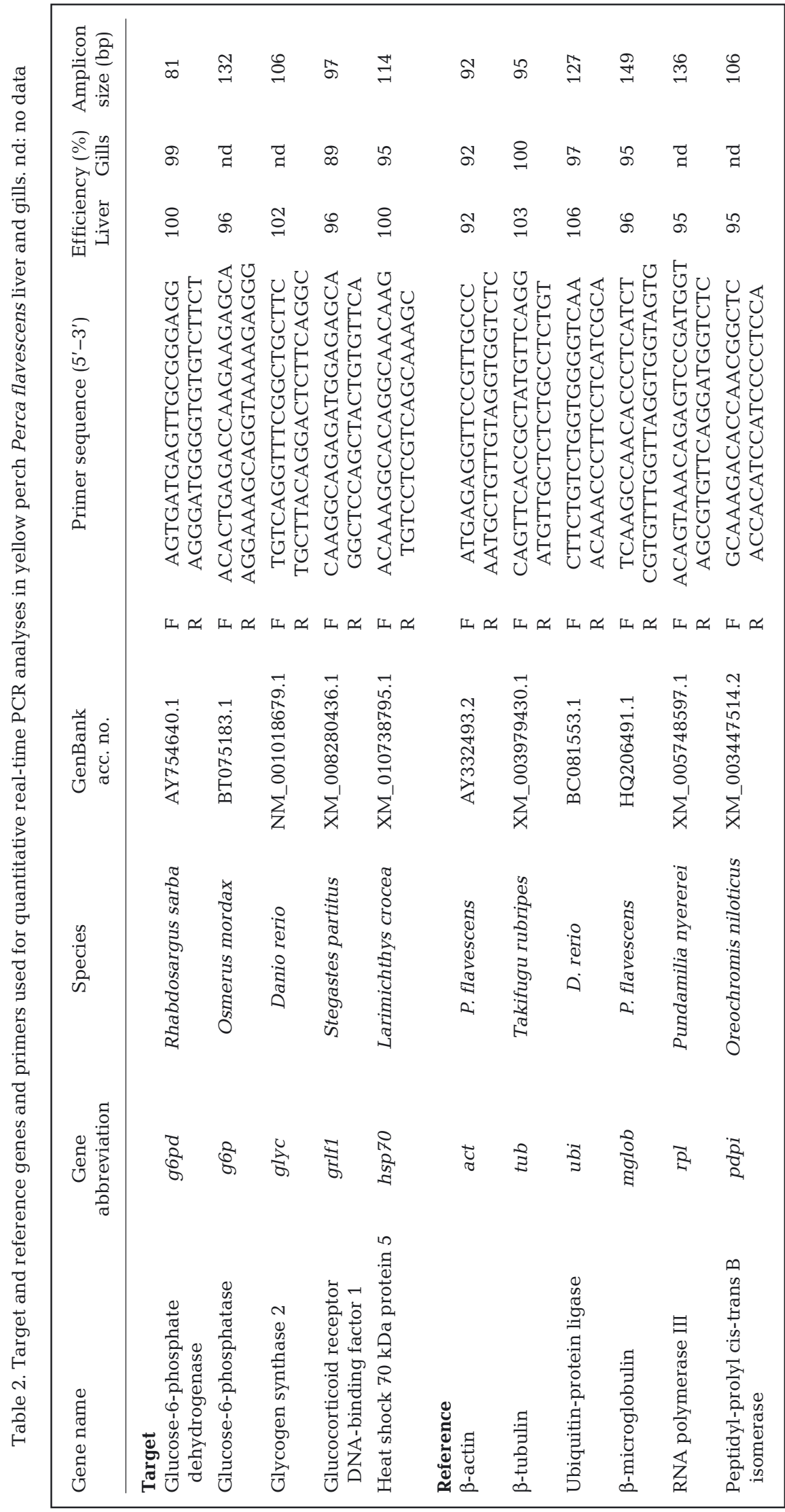

and (5) HSP70s perform chaperone functions by stabilizing and ensuring the correct folding of proteins (Mommsen et al. 1999, Padmini 2010, Polakof et al. 2012).

Primers were designed using Primer-BLAST (Primer3 with Blast) from NCBI (Rozen \& Skaletsky 2000), and the presence of secondary structures was assessed using Netprimer (Premier Biosoft). For each gene, 2 or more primer pairs were evaluated. The most efficient primer pairs were chosen for the qRT-PCR (Table 2). Primers were manufactured by IDT.

All qRT-PCR analyses were performed using $\mathrm{iQ}^{\mathrm{TM}} \mathrm{SYBR}^{\circledR}$ Green Supermix (Bio-Rad) and a CFX96 Touch $^{\text {TM }}$ Real-Time PCR Detection System (Bio-Rad) as described by Houde et al. (2014). For each primer pair selected (Table 2), a calibration curve (starting cDNA concentration: $10 \mathrm{ng}, 8$ serial dilutions, 2-, 3-, 4-, 5- or 6-fold) was established in order to obtain PCR efficiency and limit of quantification. Each reaction was run in duplicate and contained $5 \mu \mathrm{l}$ cDNA (equivalent to $10 \mathrm{ng}$ cDNA, estimated from the amount of RNA used at the reverse transcription step), $6.5 \mu \mathrm{l} \mathrm{iQ}^{\mathrm{TM}} \mathrm{SYBR}^{\circledR}$ Green Supermix, primers (300 nM each) and diethyl pyrocarbonate-treated water up to a total volume of $13 \mu \mathrm{l}$ (detailed by Sanchez et al. 2015). Cycling parameters $\left(95^{\circ} \mathrm{C}\right.$ for 2 min, 40 cycles of $95^{\circ} \mathrm{C}$ for $15 \mathrm{~s}$, and $60^{\circ} \mathrm{C}$ for $5 \mathrm{~s}$ ) were the same as previously described (Sanchez et al. 2015). To confirm specificity of the amplified product, a melting curve was generated by increasing the temperature from 57 to $95^{\circ} \mathrm{C}$ at an increment of $0.5^{\circ} \mathrm{C}$ every $5 \mathrm{~s}$. Only a single peak was observed during melting curve analyses for each gene. qRT-PCR analysis of the studied samples was run in duplicate. qRT-PCR conditions for sample analysis were the same as 
mentioned above, with the exception of cDNA quantity, which was $5 \mathrm{ng}$.

CFX Manager ${ }^{\mathrm{TM}}$ (Bio-Rad) software was used for data collection and analysis (baseline and threshold were manually set). Reference genes were selected using GenEx Enterprise software (MultiD Analyses AB) as described by Houde et al. (2014). Chosen reference genes (Table 2 ) were $\beta$-microglobulin (mglob) and $\beta$-actin (act) for liver. As for gills, reference genes for samples from the $L$. radiata experiment were ubiquitin (ubi), $\beta$-tubulin (tub) and act, and mglob, ubi and act for the E. complanata experiment (analysed with geNorm and Normfinder). When efficiency did not reach $100 \%$, Cq values were adjusted using GenEx Enterprise software (MultiD Analyses $\mathrm{AB})$. We used the comparative threshold method $(\Delta \Delta \mathrm{Ct})$ (Livak \& Schmittgen 2001) for relative quantification compared to the mean of controls. Note that, in gill tissues, only 3 genes ( $g 6 d p$, grlf 1 and hsp70) were expressed at sufficiently high levels to allow for accurate quantification.

\subsection{Statistical analyses}

Fish morphometric data were compared among control and infected groups using 1-way analyses of variances (ANOVAs). Also using ANOVAs, we compared the number of encapsulated glochidia on fish hosts between mussel species (E. complanata and $L$. radiata) and the gene transcription levels between inoculated and control groups for each studied gene and mussel species separately. Statistical analyses were performed on raw data or on normal scoretransformed data when the normality assumption was not met (Conover 1999) using the GLM procedure in SAS (SAS Institute). The significance threshold was established at $\alpha=0.05$. Note that we did not apply a post hoc adjustment of the probability (p) value, such as the Bonferroni correction, to account for the increased risk of a type 1 error (i.e. rejecting the null hypothesis given that it is true) when performing several tests (here: 1 ANOVA for each of 8 genes, 2 tissues and 2 mussel species).

\section{RESULTS}

Mean length and mass of fish did not differ significantly among control and infected groups (Table A1 in the Appendix). Young-of-the-year yellow perch inoculated with Elliptio complanata had slightly higher total glochidia (range 59-93) than fish inocu-

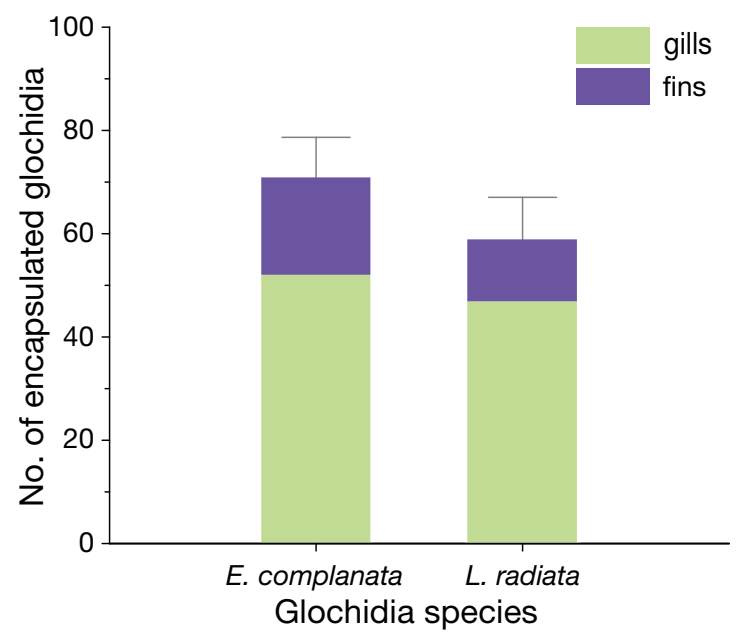

Fig. 1. Mean number of glochidia of Elliptio complanata and Lampsilis radiata attached to the gills and fins of youngof-the-year yellow perch Perca flavescens $24 \mathrm{~h}$ postinoculation. Sample size $=5$, error bars are SEM

lated with Lampsilis radiata (range 51-78), but the difference was not statistically significant $\left(F_{1,8}=1.11\right.$, $\mathrm{p}=0.3235$; Fig. 1). Most of the mussel larvae were found encysted on the gill arches or lamellae (mean \pm SEM for E. complanata $=52.0 \pm 14.7$ and for $L$. radiata $=46.8 \pm 19.5$ ) whereas a smaller number (E. comlanata $=18.8 \pm 1.9$ and for L. radiata $=12.0 \pm 5.0$ ) had clamped onto the host fins (Figs. 1 \& 2).

Analyses of transcriptomic data revealed that the gene coding for HSP70 was significantly upregulated $24 \mathrm{~h}$ post-treatment in the liver of fish inoculated with glochidia of E. complanata $\left(F_{1,8}=11.69, \mathrm{p}=0.0091\right)$ and $L$. radiata $\left(F_{1,8}=9.09, \mathrm{p}=0.0107\right)$ relative to control fish, with a 3-fold increase in the transcription level in both cases (Fig. 3). The transcription of hsp 70 was also significantly increased in the gills of infected fish relative to control but only in response to glochidia of $E$. complanata $\left(F_{1,8}=52.16, \mathrm{p}<\right.$ 0.0001), with an induction level equivalent to half that detected in the liver (Fig. 4). Furthermore, we found a significant downregulation of grlf1 $\left(F_{1,8}=\right.$ 42.29, $\mathrm{p}=0.0002)$ and glyc $\left(F_{1,8}=99.76, \mathrm{p}<0.0001\right)$ in the liver of fish exposed to glochidia of E. complanata (Fig. 3). In contrast, infection with L. radiata resulted in a non-significant upregulation of these 2 genes in the liver (grlf1: $F_{1,8}=0.73, \mathrm{p}=0.4171$; glyc: $F_{1,8}=0.38$, $\mathrm{p}=0.5557$ ). Liver transcription levels of $g 6 p d$ and g6p did not differ significantly between control and infected fish either after inoculation with glochidia of E. complanata ( $g 6 p d: F_{1,8}=2.5, \mathrm{p}=01528 ; g 6 p: F_{1,8}=$ $0.64, \mathrm{p}=0.4454)$ or L. radiata (g6pd: $F_{1,8}=3.65, \mathrm{p}=$ $\left.0.0924 ; g 6 p: F_{1,8}=0.65, \mathrm{p}=0.8335\right)$. 

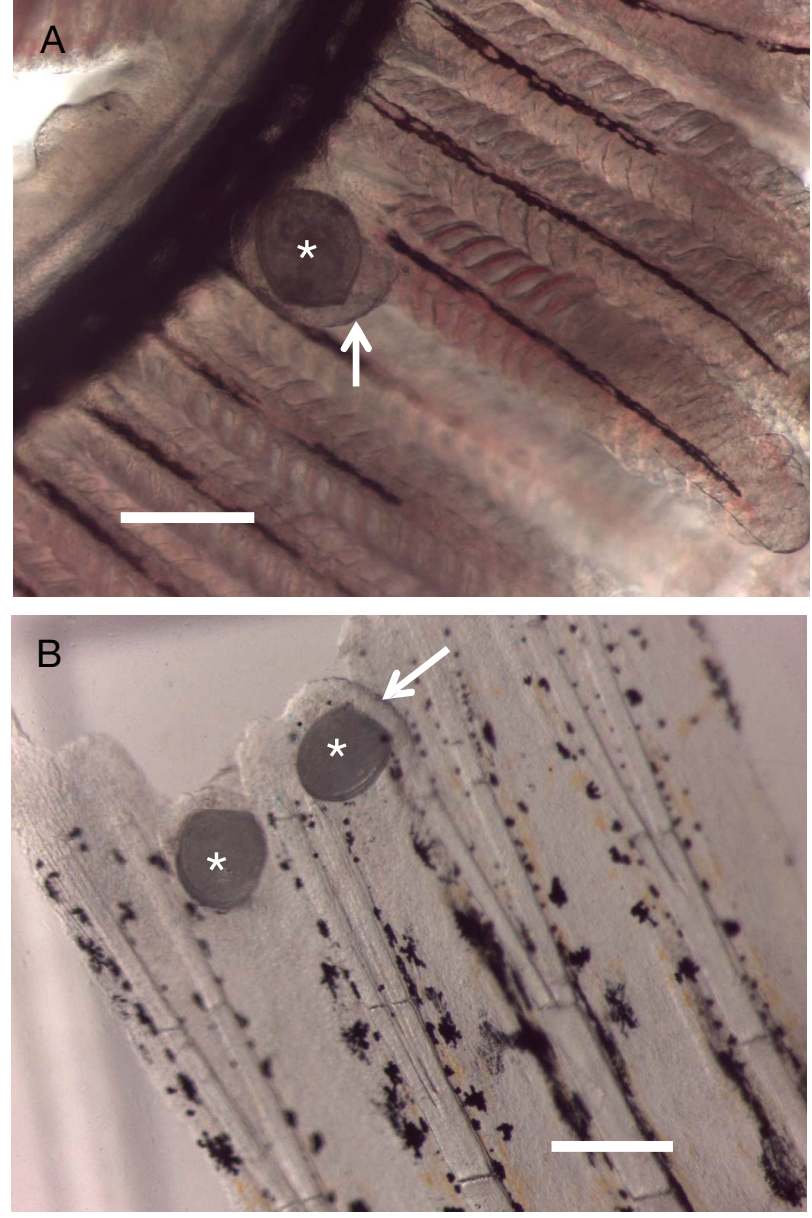

Fig. 2. Glochidia of Lampsilis radiata and of Elliptio complanata, respectively attached to (A) gill filaments and (B) the tip of a fin of a young-of-the-year yellow perch Perca flavescens. Glochidia (asterisks) are surrounded by a cyst formed of host epidermal cells (arrows). Scale bars $=250 \mu \mathrm{m}$

\section{DISCUSSION}

A number of studies have examined the effects of glochidial infection on fish host hormones, metabolites and enzymes (Table 1), but, to our knowledge, this work is the first to document early changes induced by glochidiosis at the transcriptional level.

Investigating a series of specific genes involved in fish responses to stress, we found that the transcription of the gene encoding HSP70 was significantly increased in yellow perch liver and gills $24 \mathrm{~h}$ following inoculation with glochidia of Elliptio complanata, and in the liver only in fish exposed to Lampsilis radiata. Also referred to as stress proteins, HSPs are known to respond to various stressors, including parasites and pathogens (Roberts et al. 2010, Deane \& Woo 2011, Das et al. 2015). In addition to the protec-
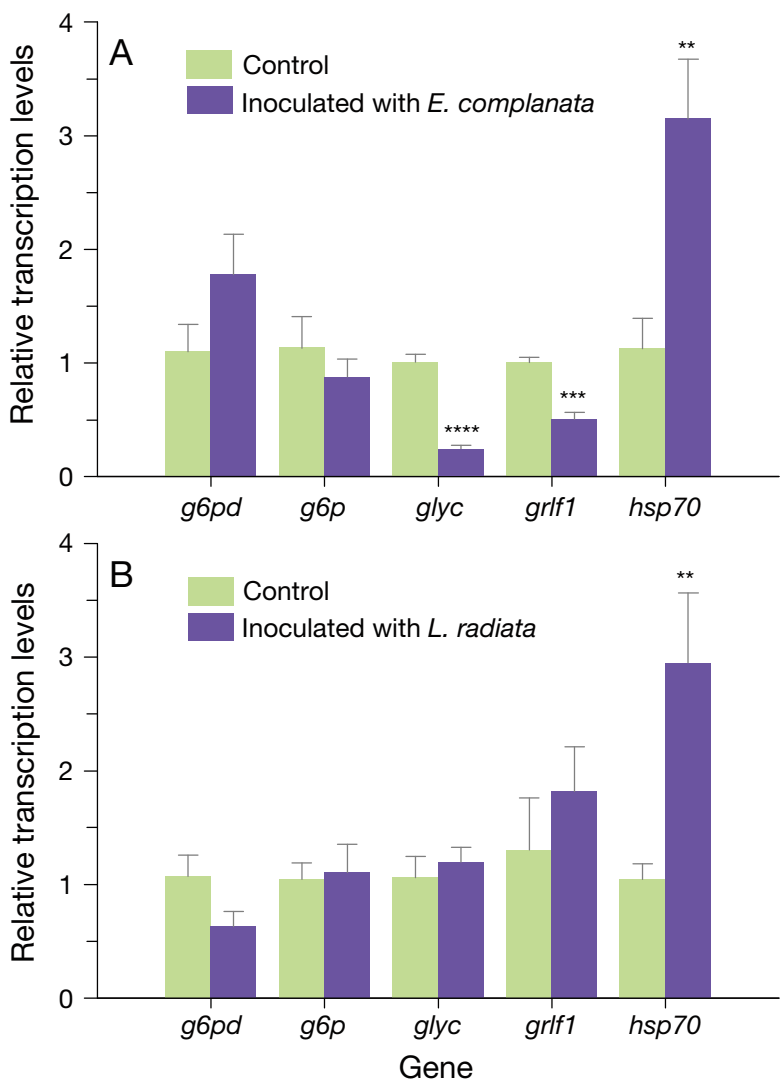

Fig. 3. Relative transcription levels of targeted genes in the liver of young-of-the-year yellow perch Perca flavescens $24 \mathrm{~h}$ after inoculation with glochidia of (A) Elliptio complanata and (B) Lampsilis radiata in comparison to control fish. g6pd: glucose-6-phosphate dehydrogenase; $g 6 p$ : glucose-6-phosphatase; glyc: glycogen synthase; grlf1: glucocorticoid receptor DNA-binding factor 1; hsp 70: heat shock $70 \mathrm{kDa}$ protein 5. Significant difference between inoculated $(N=5)$ and control fish $(\mathrm{N}=5)$ are indicated by asterisks: ${ }^{* * * *} \mathrm{p}<0.0001$; ${ }^{* * *} \mathrm{p}<0.001 ;{ }^{* *} \mathrm{p}<0.01$

tion of cellular integrity, certain families of HSPs, including HSP70, are also actively involved in the immune response, notably by acting as intercellular signalling molecules during both innate and acquired immune reactions (Deane \& Woo 2011). Previous research on the effect of infection on HSPs in fish have mainly focussed on bacterial diseases. For instance, Forsyth et al. (1997) discovered that infection of coho salmon Oncorhynchus kisutch with the pathogen Renibacterium salmoninarum responsible for bacterial kidney disease caused a sustained increase in HSP70 levels in liver and head kidney up to $63 \mathrm{~d}$ post-exposure. The hsp70 gene was also upregulated in rainbow trout $O$. mykiss after acute Vibrio anguillarum challenge (Ackerman \& Iwama 2001) and in silver sea bream Sparus sarba liver experimentally infected with $V$. alginolyticus (Deane et al. 

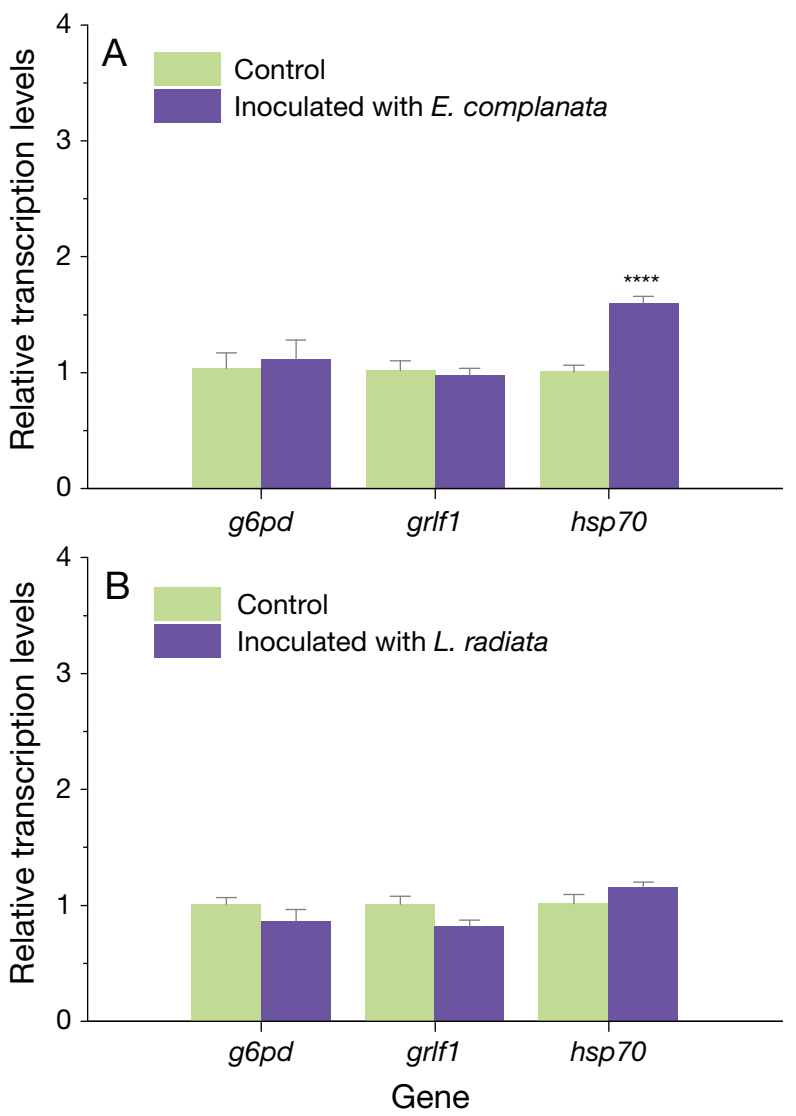

Fig. 4. Relative transcription levels of targeted genes in the gills of young-of-the-year perch Perca flavescens $24 \mathrm{~h}$ after inoculation with glochidia of (A) Elliptio complanata and (B) Lampsilis radiata in comparison to control fish. g6pd: glucose-6-phosphate dehydrogenase; grlf1: glucocorticoid receptor DNA-binding factor 1 ; hsp70: heat shock $70 \mathrm{kDa}$ protein 5. Significant difference between inoculated $(\mathrm{N}=5)$ and control fish $(\mathrm{N}=5)$ are indicated by asterisks: ${ }^{* * * *} \mathrm{p}<0.0001$

2004). Other than the results reported herein, there is no published information on the effect of glochidia or other metazoan ectoparasites on fish HSPs.

Infection of yellow perch with glochidia of E. Complanata also elicited a significant downregulation of liver glyc as well as of liver grlf1, 2 genes involved in the cortisol response to stress. Acting on nearly every tissue and organ, cortisol maintains homeostasis in fish both in response to normal changes in metabolism and during stressful perturbations (Mommsen et al. 1999). This hormone, secreted by the interrenal gland in response to corticotropin stimulation, also interferes with the immune system, strongly inhibiting inflammatory reactions (Cortés et al. 2013, Oakley \& Cidlowski 2013). Cortisol implants significantly enhance the susceptibility of fish to certain ectoparasites (Davis et al. 2003) and, as mentioned earlier, can favour the survival and metamorphosis of glochidia (Kirk \& Layzer 1997, Dubansky et al. 2011). GRLF1, by repressing the transcription of glucocorticoid receptors (LeClerc et al. 1991), reduces tissue responsiveness to cortisol stimulation. The downregulation of its coding gene would therefore be expected to cause an increase in tissue sensitivity to cortisol. Considering the anti-inflammatory effect of cortisol (Tort 2011), this early decrease in grlf1 transcripts could also indirectly contribute to protect glochidia against infiltration by host immune cells during the encapsulation process, thereby increasing their chances of survival and metamorphosis. Indeed, in the host-parasite associations studied thus far between fish and unionoid mussels, premature shedding of glochidia typically occurred within the first few days following infection (Arey 1932, Waller \& Mitchell 1989, Dubansky et al. 2011). Past this critical window, the likelihood of glochidia transforming into juveniles increased dramatically.

Host-parasite relationships are antagonistic associations where protagonists develop adaptations and counter-adaptations against each other, an evolving process often compared to an arms race (Anderson \& May 1982, Ebert \& Hamilton 1996, Sitjà-Bobadilla 2008). If the under-transcription of grlf1 observed in perch tissues actually leads to dampening the fish innate immune response, then it could hypothetically be part of the parasite counter-strategies evoked above. It is well documented that parasites belonging to various taxa can modulate the immune response of their hosts to avoid rejection and increase their survival (Hewitson et al. 2009, Coakley et al. 2016). A good example of this phenomenon among fish ectoparasites is the salmon louse Lepeophtheirus salmonis (Tadiso et al. 2011). This copepod releases a variety of secretory products (Fast et al. 2007), including trypsin-like proteases, which suppress the immune system of Atlantic salmon Salmo salar (Firth et al. 2000), reducing the phagocytic and oxidative activities of macrophages (Mustafa et al. 2000) along with the transcription of interleukins in infected hosts (Fast et al. 2006, 2007).

Interestingly, infection of yellow perch with $L$. radiata (a host specialist) did not result in an alteration of transcription for liver grlf1 or glyc as did the infection with E. complanata (a host generalist). Yet, juvenile perch were inoculated following the exact same procedures, and infected fish had a comparable number of glochidia of each species encapsulated in their gills and fins at $24 \mathrm{~h}$ post-infection. This suggests that glochidia species can differentially affect the transcription of genes modulated by cortisol secretion in 
their fish hosts. As only 2 glochidia species were compared, we can only speculate on the reasons for these differences. It is possible that unionoids interact with their host in distinct ways depending on their infection strategies or degree of host specificity, similarly to what has been suggested for insect herbivores and their plant hosts (Ali \& Agrawal 2012). According to this controversial theory, generalist insect herbivores possess mechanisms to manipulate host plants via highly conserved plant pathways, whereas specialist insect herbivores have evolved more specific mechanisms to evade the defense of their host plants (Ali \& Agrawal 2012).

Additional research is needed to understand the underlying mechanisms and the actual significance of the observed changes in gene transcription following glochidial infection. In particular, the above interpretations and hypotheses regarding the gene encoding GRLF1 should be considered with caution, given that the functions of this factor are complex and only beginning to be understood. A more comprehensive representation of the fish response to glochidiosis could be obtained using high-throughput genomic and proteomic technologies. These techniques could also help identify potential secretory/excretory products of glochidia acting as modulators of the fish response to infection (Hewitson et al. 2009).

A better understanding of this host-parasite association is particularly relevant in the context of freshwater mussel conservation. Indeed, unionoids have dramatically declined over the last centuries both in North America and in Europe due to the cumulative impact of a variety of anthropogenic stressors, and the recovery of many species now relies on captive propagation programs where fish are raised as hosts for the production of juvenile mussels (Kirk \& Layzer 1997, Neves 2004, Haag 2012, Nelson \& Bringolf 2018).

Acknowledgements. We thank Germain Brault, Michel Arseneau, Sophie Trépanier, Maude Lachapelle and Jocelyn Rolland, from the Water Science and Technology Directorate of Environment and Climate Change Canada, and Annie Paquet from the Ministère des Forêts, de la Faune et et des Parcs du Québec for their assistance in the field and/or with the maintenance of fish/mussels in the laboratory. This study supports the St. Lawrence Action Plan and was in part financed by the Strategic Technology Application of Genomics in the Environment (STAGE) programme.

\section{LITERATURE CITED}

Ackerman PA, Iwama GK (2001) Physiological and cellular stress responses of juvenile rainbow trout to Vibriosis. J Aquat Anim Health 13:173-180
Ali JG, Agrawal AA (2012) Specialist versus generalist insect herbivores and plant defense. Trends Plant Sci 17: 293-302

Anderson RM, May RM (1982) Coevolution of hosts and parasites. Parasitology 85:411-426

Arey LB (1932) A microscopical study of glochidia immunity. J Morphol 53:367-379

Barnhart CM, Riusech FA, Baird MS (1998) Drum is host of the scaleshell, Leptodea leptodon. Triannu Unionid Rep 16:35

Barnhart MC, Haag WR, Roston WN (2008) Adaptations to host infection and larval parasitism in Unionoida. J N Am Benthol Soc 27:370-394

Bauer G, Vogel C (1987) The parasitic stage of the freshwater pearl mussel (Margaritifera margaritifera L.) I. Host response to glochidiosis. Arch Hydrobiol Suppl 76: 393-402

Coakley G, Buck AH, Maizels RM (2016) Host parasite communications - messages from helminths for the immune system. Mol Biochem Parasitol 208:33-40

Conover W (1999) Practical non-parametric statistics. John Wiley \& Sons, New York, NY

Cortés R, Teles M, Trídico R, Acerete L, Tort L (2013) Effects of cortisol administered through slow-release implants on innate immune responses in rainbow trout (Oncorhynchus mykiss). Int J Genomics 2013:619714

* Das S, Mohapatra A, Sahoo PK (2015) Expression analysis of heat shock protein genes during Aeromonas hydrophila infection in rohu, Labeo rohita, with special reference to molecular characterization of Grp78. Cell Stress Chaperones 20:73-84

Davis KB, Griffin BR, Gray WL (2003) Effect of dietary cortisol on resistance of channel catfish to infection by Ichthyopthirius multifiliis and channel catfish virus disease. Aquaculture 218:121-130

Deane EE, Woo NYS (2011) Advances and perspectives on the regulation and expression of piscine heat shock proteins. Rev Fish Biol Fish 21:153-185

* Deane EE, Li J, Woo NYS (2004) Modulated heat shock protein expression during pathogenic Vibrio alginolyticus stress of sea bream. Dis Aquat Org 62:205-215

* Dodd BJ, Barnhart MC, Rogers-Lowery CL, Fobian TB, Dimock RVJ (2005) Cross-resistance of largemouth bass to glochidia of unionid mussels. J Parasitol 91:1064-1072

* Dodd BJ, Barnhart CM, Rogers-Lowery CL, Fobian TB, Dimock RV Jr (2006) Persistence of host response against glochidia larvae in Micropterus salmoides. Fish Shellfish Immunol 21:473-484

* Douda K, Velíšek J, Kolářová J, Rylková K, Slavík O, Horký P, Langrová I (2017) Direct impact of invasive bivalve (Sinanodonta woodiana) parasitism on freshwater fish physiology: evidence and implications. Biol Invasions 19: 989-999

*Douda K, Martin M, Glidewell E, Barnhart C (2018) Stressinduced variation in host susceptibility to parasitic freshwater mussel larvae. Hydrobiologia 810:265-272

Dubansky B, Whitaker B, Galvez F (2011) Influence of cortisol on the attachment and metamorphosis of larval Utterbackia imbecillis on bluegill sunfish (Lepomis macrochirus). Biol Bull (Woods Hole) 220:97-106

Ebert D, Hamilton W (1996) Sex against virulence: the coevolution of parasitic diseases. Trends Ecol Evol 11: 79-82

Fast MD, Muise DM, Easy RE, Ross NW, Johnson SC (2006) The effects of Lepeophtheirus salmonis infections on the 
stress response and immunological status of Atlantic salmon (Salmo salar). Fish Shellfish Immunol 21:228-241

Fast MD, Johnson SC, Eddy TD, Pinto D, Ross NW (2007) Lepeophtheirus salmonis secretory/excretory products and their effects on Atlantic salmon immune gene regulation. Parasite Immunol 29:179-189

Filipsson K, Brijs J, Näslund J, Wengström N and others (2017) Encystment of parasitic freshwater pearl mussel (Margaritifera margaritifera) larvae coincides with increased metabolic rate and haematocrit in juvenile brown trout (Salmo trutta). Parasitol Res 116:1353-1360

Firth KJ, Johnson SC, Ross NW (2000) Characterization of proteases in the skin mucus of Atlantic salmon (Salmo salar) infected with the salmon louse (Lepeophtheirus salmonis) and in whole-body louse homogenate. J Parasitol 86:1199-1205

Fisher GR, Dimock RV (2002) Morphological and molecular changes during metamorphosis in Utterbackia imbecillis (Bivalvia: Unionidae). J Molluscan Stud 68:159-164

Forsyth RB, Candido EPM, Babich SL, Iwama GK (1997) Stress protein expression in coho salmon with bacterial kidney disease. J Aquat Anim Health 9:18-25

Haag WR (2012) North American freshwater mussels: natural history, ecology and conservation. Cambridge University Press, Cambridge

Haag WR, Warren ML (1999) Mantle displays of freshwater mussels elicit attacks from fish. Freshw Biol 42:35-40

Haag WR, Butler RS, Hartfield PD (1995) An extraordinary reproductive strategy in freshwater bivalves: prey mimicry to facilitate larval dispersal. Freshw Biol 34:471-476

Hewitson JP, Grainger JR, Maizels RM (2009) Helminth immunoregulation: the role of parasite secreted proteins in modulating host immunity. Mol Biochem Parasitol 167: $1-11$

Houde M, Giraudo M, Douville M, Bougas B and others (2014) A multi-level biological approach to evaluate impacts of a major municipal effluent in wild St. Lawrence River yellow perch (Perca flavescens). Sci Total Environ 497-498:307-318

Howerth EW, Keller AE (2006) Experimentally induced glochidiosis in smallmouth bass (Micropterus dolomieu). Vet Pathol 43:1004-1007

Kaiser BE (2005) The effects of glochidiosis on fish respiration. MSc thesis, Missouri State University, Springfield, $\mathrm{MO}$

Karna DW, Milemann RE (1978) Glochidiosis of salmonid fishes. III. Comparative susceptibility to natural infection with Margaritifera margaritifera (L.) (Pelecypoda: Margaritanidae) and associated histopathology. J Parasitol 64:528-537

Kirk SG, Layzer JB (1997) Induced metamorphosis of freshwater mussel glochidia on nonhost fish. Nautilus 110: 102-106

Kneeland SC, Rhymer JM (2008) Determination of fish host use by wild populations of rare freshwater mussels using a molecular identification key to identify glochidia. J N Am Benthol Soc 27:150-160

LeClerc S, Palaniswami R, Xie BX, Govindan MV (1991) Molecular cloning and characterization of a factor that binds the human glucocorticoid receptor gene and represses its expression. J Biol Chem 266:17333-17340

Lellis WA, White BSJ, Cole JC, Johnson CS, Devers JL, Gray EVS, Galbraith HS (2013) Newly documented host fishes for the eastern elliptio mussel Elliptio complanata. J Fish Wildl Manag 4:75-85
Livak KJ, Schmittgen TD (2001) Analysis of relative gene expression data using real-time quantitative PCR and the 2- $\Delta \Delta \mathrm{Ct}$ method. Methods 25:402-408

Matteson MR (1948) Life history of Elliptio complanatus (Dillwyn, 1817). Am Midl Nat 40:690-723

* Mommsen TP, Mathilakath MV, Moon TW (1999) Cortisol in teleosts: dynamics, mechanisms of action, and metabolic regulation. Rev Fish Biol Fish 9:211-268

Mustafa A, MacWilliams C, Fernandez N, Matchett K, Conboy G, Burka J (2000) Effects of sea lice (Lepeophtheirus salmonis Kroyer, 1837) infestation on macrophage functions in Atlantic salmon (Salmo salar L.). Fish Shellfish Immunol 10:47-59

Nelson JM, Bringolf RB (2018) Potential enhancement of juvenile mussel production with exogenous cortisol treatment of fish hosts. N Am J Aquacult 80:153-161

Neves RJ (2004) Propagation of endangered freshwater mussels in North America. J Conchol Spec Publ 3: 69-80

O'Connell MT, Neves RJ (1999) Evidence of immunological response by a host fish (Ambloplites rupestris) and two non-host fishes (Cyprinus carpio and Carassius auratus) to glochidia of a freshwater mussel (Villosa iris). J Freshw Ecol 14:71-78

Oakley RH, Cidlowski JA (2013) The biology of the glucocorticoid receptor: new signaling mechanisms in health and disease. J Allergy Clin Immunol 132:1033-1044

* Ooue K, Terui A, Urabe H, Nakamura F (2017) A delayed effect of the aquatic parasite Margaritifera laevis on the growth of the salmonid host fish Oncorhynchus masou masou. Limnology 18:345-351

Padmini E (2010) Physiological adaptations of stressed fish to polluted environments: role of heat shock proteins. Rev Environ Contam Toxicol 206:1-27

*Polakof S, Panserat S, Soengas JL, Moon TW (2012) Glucose metabolism in fish: a review. J Comp Physiol B 182: 1015-1045

Keis J, Collares-Pereira MJ, Araujo R (2014) Host specificity and metamorphosis of the glochidium of the freshwater mussel Unio tumidiformis (Bivalvia: Unionidae). Folia Parasitol 61:81-89

Koberts RJ, Agius C, Saliba C, Bossier P, Sung YY (2010) Heat shock proteins (chaperones) in fish and shellfish and their potential role in relation to fish health: a review. J Fish Dis 33:789-801

* Rogers-Lowery CL, Dimock RV (2006) Encapsulation of attached ectoparasitic glochidia larvae of freshwater mussels by epithelial tissue on fins of native and resistant host fish. Biol Bull (Woods Hole) 210:51-63

Rozen S, Skaletsky HJ (2000) Primer3 on the WWW for general users and for biologist programmers. In: Krawetz S, Misener S (eds) Bioinformatics methods and protocols: methods in molecular biology. Humana Press, Totowa, NJ, p 365-386

* Sanchez D, Houde M, Douville M, De Silva AO, Spencer C, Verreault J (2015) Transcriptional and cellular responses of the green alga Chlamydomonas reinhardtii to perfluoroalkyl phosphonic acids. Aquat Toxicol 160:31-38

* Sitjà-Bobadilla A (2008) Living off a fish: a trade-off between parasites and the immune system. Fish Shellfish Immunol 25:358-372

Tadiso TM, Krasnov A, Skugor S, Afanasyev S, Hordvik I, Nilsen F (2011) Gene expression analyses of immune responses in Atlantic salmon during early stages of infection by salmon louse (Lepeophtheirus salmonis) revealed 
bi-phasic responses coinciding with the copepod-chalimus transition. BMC Genomics 12:141

Tedla S, Fernando CH (1969) Observations on the glochidia of Lampsilis radiata (Gmelin) infesting yellow perch, Perca flavescens (Mitchill) in the Bay of Quinte, Lake Ontario. Can J Zool 47:705-712

Thomas GR, Taylor J, Garcia de Leaniz C (2014) Does the parasitic freshwater pearl mussel $M$. margaritifera harm its host? Hydrobiologia 735:191-201

Tort L (2011) Stress and immune modulation in fish. Dev Comp Immunol 35:1366-1375

Treasurer JW, Hastie LC, Hunter D, Duncan F, Treasurer CM (2006) Effects of (Margaritifera margaritifera) glochidial infection on performance of tank-reared Atlantic salmon (Salmo salar). Aquaculture 256:74-79

Van Snik Gray E, Lellis WA, Cole JC, Johnson CS (2002) Host identification for Strophitus undulatus (Bivalvia: Unionidae), the creeper, in the Upper Susquehanna River Basin, Pennsylvania. Am Midl Nat 147:153-161

Waller DL, Mitchell LG (1989) Gill tissue reactions in walleye Stizostedion vitreum vitreum and common carp
Cyprinus carpio to glochidia of the freshwater mussel Lampsilis radiata siliquoidea. Dis Aquat Org 6:81-87

Watters GT (1999) Morphology of the conglutinate of the kidneyshell freshwater mussel, Ptychobranchus fasciolaris. Invertebr Biol 118:289-295

Watters GT (2002) The kinetic conglutinate of the creeper freshwater mussel, Strophitus undulatus (Say, 1817). J Molluscan Stud 68:155-158

WWatters GT, O'Dee SH (1998) Metamorphosis of freshwater mussel glochidia (Bivalvia: Unionidae) on amphibians and exotic fishes. Am Midl Nat 139:49-57

* Watters GT, O'Dee SH (1999) Glochidia of the freshwater mussel Lampsilis overwintering on fish hosts. J Molluscan Stud 65:453-459

Zale AV, Neve RJ (1982) Identification of a host fish for Alasmidonta minor (Mollusca: Unionidae). Am Midl Nat 107: 386-388

Zanatta DT, Murphy RW (2006) Evolution of active hostattraction strategies in the freshwater mussel tribe Lampsilini (Bivalvia: Unionidae). Mol Phylogenet Evol 41: 195-208

\section{Appendix.}

Table A1. Morphometrics of young-of-the-year yellow perch Perca flavescens used in the experimental infections with glochidia of Elliptio complanata and Lampsilis radiata. Measurements are expressed as mean \pm SEM. df1 (df2): between (within) group degrees of freedom

\begin{tabular}{|c|c|c|c|}
\hline \multirow{2}{*}{ Experiments } & \multirow[b]{2}{*}{$\mathrm{N}$} & - Test fish & \multirow[b]{2}{*}{ Mass (g) } \\
\hline & & Total length (mm) & \\
\hline \multicolumn{4}{|c|}{ E. complanata } \\
\hline Control & 5 & $58.8 \pm 1.7$ & $1.88 \pm 0.17$ \\
\hline Inoculated & 5 & $62.8 \pm 1.7$ & $1.94 \pm 0.18$ \\
\hline \multicolumn{4}{|l|}{ L. radiata } \\
\hline Control & 5 & $60.6 \pm 1.6$ & $2.09 \pm 0.21$ \\
\hline Inoculated & 5 & $62.4 \pm 1.7$ & $2.25 \pm 0.18$ \\
\hline \multicolumn{4}{|c|}{ ANOVA results } \\
\hline$F(\mathrm{df} 1, \mathrm{df} 2)$ & & $1.17(3,16)$ & $2.33(3,16)$ \\
\hline $\mathrm{p}$ & & 0.3513 & 0.1134 \\
\hline
\end{tabular}

Editorial responsibility: Catherine Collins, Aberdeen, UK
Submitted: March 12, 2018; Accepted: November 9, 2018 Proofs received from author(s): January 20, 2019 